\title{
Meningkatkan Kemampuan Guru dalam Melaksanakan Pembelajaran yang Efektif Melalui Pelaksanaan Supervisi Klinis dengan Mengikuti Alur Pembelajaran Inkuiri
}

\author{
I Made Suyasa \\ SD Negeri 2 Gianyar \\ e-mail: madesuyasa45@gmail.com
}

\begin{abstract}
Abstrak
Penelitian tindakan Sekolah yang dilakukan ini bertujuan untuk meningkatkan kemampuan guru dalam melaksanakan proses pembelajaran yang efektif di SD Negeri 2 Gianyar pada semester II tahun pelajaran 2017/2018 melalui pelaksanaan supervisi klinis dengan mengikuti alur pembelajaran inquiri. Data hasil penelitian ini dikumpulkan dengan cara melakukan supevisi dengan instrumen. Dalam menganalisis data yang diperoleh digunakan metode analisis deskriptif. Data yang dihasilkan dari penelitian ini terdiri dari data awal, data siklus I dan data Siklus II. Dari data awal diperoleh rata-rata kemampuan melaksanakan proses pembelajaran yang efektif, hanya mencapai nilai 72,76 dan ketuntasan baru mencapai $19,04 \%$. Data ini jauh di bawah harapan mengingat ketuntasan pelaksanaan proses pembelajaran minimal 78,38 . Rata-rata nilai siklus I sudah terjadi peningkatan yaitu rata-ratanya mencapai 78,85 dan prosentase ketuntasannya mencapai $33,33 \%$. Pada siklus II perolehan rata-ratanya sudah mencapai 89,04 dan persentase ketuntasan sudah mencapai 100\%. Data pada Siklus II ini sudah sesuai harapan, yaitu kemampuan guru dalam melaksanakan proses pembelajaran yang efektif di SD Negeri 2 Gianyar pada semester II tahun pelajaran 2017/2018 mengalami peningkatan melalui pelaksanaan supervisi klinis dengan mengikuti alur pembelajaran inquiri.
\end{abstract}

Kata Kunci: Kemampuan Guru, Supervisi Klinis, Pembelajaran Inquiri

\begin{abstract}
The School Action Research conducted aims to improve the ability of teachers to carry out effective learning processes in Gianyar Elementary School 2 in the second semester of the $2017 / 2018$ school year through the implementation of clinical supervision by following the flow of inquiry learning. Data from the results of this study were collected by revising with instruments. In analyzing the data obtained used descriptive analysis method. The data generated from this study consisted of preliminary data, first cycle data and Cycle II data. From the initial data obtained the average ability to carry out effective learning processes, only reached a value of 72.76 and completeness only reached $19.04 \%$. This data is far below expectations given that the completeness of the learning process is at least 78.38. The average value of the first cycle has increased, the average reached 78.85 and the percentage of completeness reached $33.33 \%$. In the second cycle the acquisition has reached 89.04 and the percentage of completeness has reached 100\%. Data in Cycle II has been in line with expectations, namely the ability of teachers to carry out effective learning processes in Gianyar Elementary School 2 in the second semester of 2017/2018 lessons experienced an increase through the implementation of clinical supervision by following the flow of inquiry learning.
\end{abstract}

Keywords: Teacher Ability, Clinical Supervision, Inquiry Learning 


\section{Pendahuluan}

Pentingnya pendidikan telah ditegaskan dalam Pembukaan UUD 1945 yang menyatakan bahwa salah satu tujuan negara adalah mencerdaskan kehidupan bangsa. Upaya mencerdaskan kehidupan bangsa ini tentunya memerlukan proses pendidikan. Pentingnya pendidikan ini juga ditegaskan dalam UU Nomor 20 Tahun 2003 tentang Sisdiknas. Yakni, pendidikan merupakan usaha sadar dan terencana untuk mewujudkan suasana belajar dan proses pembelajaran agar peserta didik secara aktif mengembangkan potensi dirinya untuk memiliki kekuatan spiritual keagamaan, pengendalian diri, kepribadian, ahlak mulia, serta ketrampilan yang diperlukan dirinya, masyarakat, bangsa, dan Negara. Untuk menyelenggarakan proses pendidikan tersebut membutuhkan guru yang berperan sebagai pembimbing, motivator, dan stimulator bagi anak didiknya. Peserta didik perlu dibantu untuk mengembangkan potensi dirinya dengan cara dibimbing, dimotivasi, dan diberi stimulus dengan berbagai pertanyaan agar potensi intelektualnya terus berkembang. Setiap manusia dalam kodratnya adalah pembelajar yang cerdas. Mereka dianugrahi oleh Tuhan dengan rasa ingin tahu (curiosity) sebagai modal untuk mengembangkan intelektualnya (Warsono, 2017).

Pendidikan adalah hal terpenting bagi setiap negara untuk dapat berkembang pesat. Negara yang hebat akan menempatkan pendidikan sebagai prioritas pertamanya, karena dengan pendidikan, kemiskinan pada rakyat di negara tersebut akan dapat tergantikan menjadi kesejahteraan. Bagaimanapun, dalam perkembangannya, pendidikan di Indonesia senantiasa harus menghadapi beberapa masalah di setiap tahapnya. Masalahmasalah tersebut hanya dapat diselesaikan dengan partisipasi dari semua pihak yang terkait di dalam sistem pendidikan, seperti orangtua, guru-guru, kepala sekolah, masyarakat, dan juga peserta didik itu sendiri (Megawati, 2012).

Pasal 1 UU SISDIKNAS no. 20 tahun 2003 disebutkan bahwa Sistem Pendidikan Nasional adalah keseluruhan komponen pendidikan yang saling terkait secara terpadu untuk mencapai tujuan pendidikan nasional. Berangkat dari bunyi pasal ini dapat diketahui bahwa pendidikan adalah sistem yang merupakan suatu totalitas struktur yang terdiri dari komponen yang saling terkait dan secara bersama menuju kepada tercapainya tujuan (Soetarno, 2003: 2). Adapun komponen-komponen dalam pendidikan nasional antara lain adalah lingkungan, sarana-prasarana, sumberdaya, dan masyarakat. Komponen-komponen tersebut bekerja secara bersama-sama, saling terkait dan mendukung dalam mencapai tujuan pendidikan. Tujuan pendidikan nasional yang dirumuskan dalam UU SISDIKNAS adalah untuk mengembangkan potensi anak didik agar menjadi manusia yang beriman dan bertakwa kepada Tuhan Yang Maha Esa, berakhlak mulia, sehat, berilmu, cakap, kreatif, mandiri, dan menjadi warga Negara yang demokratis serta bertanggung jawab (Munirah, 2015).

Cara pembelajaran guru yang terus-menerus menggunakan model pembelajaran konvensional harus segera diakhiri, sudah berkembang begitu pesat dan maju. Kebiasaan guru mengajar dengan sistem lama harus segera mendapat penanganan oleh pengawas sekolah. Guru-guru harus berupaya melakukan pembelajaran menggunakan model-model pembelajaran yang didasari teori-teori yang benar. Tidak terbantahkan lagi bahwa pengawas sekolah harus mampu meningkatkan kemampuan guru melaksanakan proses pembelajaran. Tugas pengawas sekolah dalam hal ini adalah tugas wajib untuk semua pengawas sekolah, sehingga penelitian yang dilakukan bisa saja sama dalam meningkatkan proses pembelajaran namun pada subjek dan tempat yang berbeda.

Salah satu aspek yang menarik untuk dikaji dari sosok seorang guru adalah aspek kinerja, karena kinerja guru menurut merupakan input yang paling penting dalam penyelenggaraan pendidikan (Nadeem \& et.al, 2011). Akan tetapi berdasarkan Fakta menunjukkan kinerja guru masih belum optimal. Belum optimalnya kinerja guru, hal tersebut ditunjukkan antara lain guru tidak membuat Rencana Pelaksanaan Pembelajaran (RPP), mengabaikan kelengkapan administrasi guru, memberikan tugas tanpa adanya proses tatap muka, kurangnya bahan ajar yang menarik penggunaan model dan metode yang monoton, dan evaluasi pembelajaran yang belum optimal (Kesuma, 2017).

Guru menjadi faktor yang menentukan mutu pendidikan karena guru berhadapan langsung dengan para peserta didik dalam proses pembelajaran di kelas. Di tangan guru, mutu dan kepribadian peserta didik dibentuk. Karena itu, perlu sosok guru kompeten, bertanggung jawab, terampil, dan berdedikasi tinggi. Guru adalah kurikulum berjalan. Sebaik apa kurikulum dan sistem pendidikan yang ada tanpa didukung oleh kemampuan guru, semuanya akan siasia. Guru berkompeten dan bertanggung jawab, utamanya dalam mengawal perkembangan 
peserta didik sampai ke suatu titik maksimal. Tujuan akhir seluruh proses pendampingan guru adalah tumbuhnya pribadi dewasa yang utuh (Shabir, 2015).

Peran guru dan peserta didik yang dimaksud di sini adalah berkaitan dengan peran dalam proses pembelajaran. Guru dan peserta didik merupakan faktor penentu yang sangat dominan dalam pendidikan umumnya, karena guru dan peserta didik memegang peranan dalam proses pembelajaran, di mana proses pembelajaran merupakan inti dari proses pendidikan secara keseluruhan yang bertujuan terjadinya perubahan tingkah laku anak (Kirom, 2017).

Pembelajaran di sekolah akan sangat efektif apabila guru melaksanakannya dengan memahami peran, fungsi dan kegunaan mata pelajaran yang diajarnya. Di samping pemahaman akan hal-hal tersebut keefektipan itu juga ditentukan oleh kemampuan guru untuk merubah paradigma pengajaran menjadi pembelajaran.

Beberapa model pembelajaran terbaru harus diupayakan guru demi berhasilnya pengembangan intelektual, sosial dan emosional yang akan berperan sebagai kunci penentu menuju keberhasilan peningkatan hasil belajar. Fungsi mata pelajaran yang diampu perlu untuk dipahami oleh pengawas untuk mempersiapkan guru mampu merefleksikan pengalamannya sendiri, pengalaman orang lain, mengungkapkan gagasan-gagasan dan perasaan serta memahami beragam nuansa makna. Di samping mengetahui peran, fungsi dan kegunaan mata pelajaran yang diampu, sebagai seorang guru juga diperlukan untuk mampu menerapkan beberapa alur dan metode ajar sehingga paradigma pengajaran dapat dirubah menjadi paradigma pembelajaran.

Kelemahan-kelemahan di lapangan selama proses pembelajran yang dilakukan di SD Negeri 2 Gianyar pada semester II tahun pelajaran 2017/2018 yang menyebabkan rendahnya kemampuan guru dalam melaksanakan proses pembelajaran yang efektif, tidak sepenuhnya disebabkan oleh faktor luar seperti kesibukan guru, keadaan rumah tangga, lingkungan dan lain-lain. Kelemahan-kelemahan yang ada banyak pula dipengaruhi oleh faktor dari dalam guru itu sendiri seperti kemauan menyiapkan bahan yang lebih baik, kemauan menyiapkan mediamedia pembelajaran yang menarik.

Semua uraian di atas menunjukkan hal-hal yang perlu dilakukan dalam upaya meningkatkan kemampuan guru melaksanakan proses pembelajaran melalui pelaksanaan supervisi klinis dengan mengikuti alur pembelajaran inquiri. Apabila betul-betul guru menguasai dan mengerti tentang hal-hal tersebut dapat diyakini bahwa kemampuan guru dalam proses pembelajaran bisa ditingkatkan. Namun kenyataannya kemampuan guru dalam melaksanakan proses pembelajaran yang efektif di SD Negeri 2 Gianyar hanya mencapai rata-rata 72,76 dengan kualifikasi C (cukup) yaitu ketuntasan guru hanya mencapai $19,04 \%$. Hal ini sangat jauh dari indikator keberhasilan yang mengharapkan kualifikasi $A$ (amat baik) dengan rentang nilai dari 86-100.

Melihat kesenjangan antara harapan-harapan yang telah disampaikan dengan kenyataan lapangan sangat jauh berbeda, dalam upaya memperbaiki mutu pendidikan sangat perlu kiranya dilakukan perbaikan cara pembelajaran. Salah satunya adalah perbaikan pembelajaran dengan pelaksanaan supervisi klinis dengan mengikuti alur pembelajaran inquiri Sebagai upaya untuk meningkatkan kemampuan guru dalam melaksanakan proses pembelajaran yang efektif. Oleh karenanya penelitian ini sangat penting untuk dilaksanakan.

Rumusan masalah dalam penelitian ini terurai sebagai beriku: Apakah penerapan supervisi klinis dengan mengikuti alur pembelajaran inquiri mampu meningkatkan kemampuan guru dalam dalam melaksanakan proses pembelajaran yang efektif di SD Negeri 2 Gianyar pada semester II tahun pelajaran 2017/2018? Tujuan penelitian ini adalah Untuk meningkatkan kemampuan guru dalam dalam melaksanakan proses pembelajaran yang efektif di SD Negeri 2 Gianyar pada semester II tahun pelajaran 2017/2018 melalui pelaksanaan supervisi klinis dengan mengikuti alur pembelajaran inquiri.

\section{Metode}

Penelitian yang dilakukan di SD Negeri 2 Gianyar di harapkan mampu meningkatkan kemampuan gugu-guru dalam pelaksanaan proses pembelajaran. Penelitian tindakan ini terfokus pada penelitian tindakan sekolah.

Untuk penelitian ini penulis memilih rancangan penelitian tindakan yang disampaikan oleh Dave Ebbut seperti terlihat pada gambar berikut: 


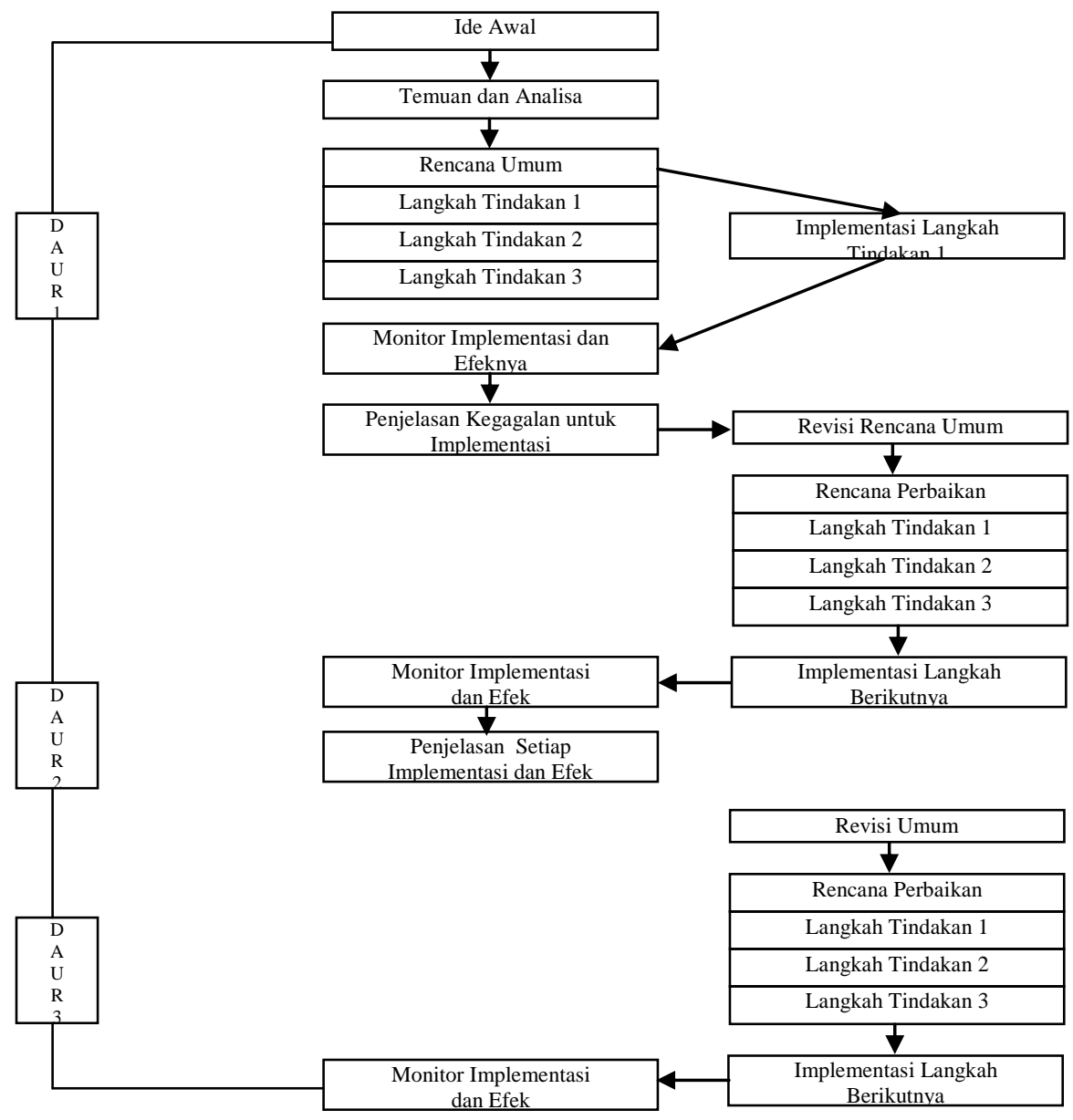

Gambar 1. Rancangan Penelitian Tindakan

Prosedur:

Sebagai alur PTK, Ebbut memberi contoh sebagai berikut:

Pada daur I dimulai dengan adanya ide awal akibat temuan dan analisis yang telah dilakukan. Setelah ada temuan tersebut dibuatlah perencanaan umum sesuai langkah yang direncanakan baik tindakan 1, tindakan 2 maupun tindakan 3. Sesudah membuat perencanaan, diimplementasikan dalam tingkat 1 , dimonitoring implementasinya serta efeknya kemudian dijelaskan kegagalan-kegagalan yang ada selama implementasinya lalu dibuat revisi umum untuk perencanaan tindakan selanjutnya.

Pada tindakan selanjutnya, perencanaan yang telah dibuat diimplementasikan, terus dimonitor implementasinya serta efek yang ada, dijelaskan setiap langkah implementasinya dan efeknya.Setelah mengetahui bagaimana hasil dan efeknya, dibuat lagi perencanaan untuk tindakan selanjutnya. Demikian berlanjut sampai menemukan hasil yang sesuai tujuan yang direncanakan.

Subjek penelitian ini adalah guru-guru di SD Negeri 2 Gianyar dalam pelaksanaan proses pembelajaran semester II tahun pelajaran 2017/2018. Objek Penelitian ini adalah peningkatan kemampuan guru-guru dalam melaksanakan proses pembelajaran yang efektif melalui pelaksanaan supervisi klinis dengan mengikuti alur pembelajaran inquiri.

Penelitian tindakan sekolah yang dilakukan ini sudah sudah terjadwal sedemikian rupa yaitu dari bulan Januari sampai bulan Juni pada semester II tahun pelajaran 2017/2018. Kegiatannya termasuk perencanaan/pembuatan proposal pelaksanaan, observasi/pengambilan data dan refleksi.

Metode mengumpulkan data adalah observasi. Observasi adalah suatu teknik atau cara mengumpulkan data dengan jalan mengadakan pengamatan terhadap kegiatan yang sedang berlangsung, kegiatan tersebut bisa memberikan pengarahan, personil bidang kepegawaian yang sedang rapat, dsb (Sukmadinata, 2007: 220). Setelah kegiatan supervisi individual ini berlangsung dilakukan kegiatan supervisi seperti: diksusi, tanya jawab, unjuk kerja dan bersama-sama melakukan studi dokumen terhadap buku-buku pegangan guru. Hasil tanya 
jawab tidak dipaparkan karena hal tersebut merupakan langkah untuk memperkuat kemampuan guru-guru melaksanakan proses pembelajaran untuk menopang kegiatan nyata yang dilakukan. Unjuk kerja dilakukan dengan melakukan proses pembelajaran setelah mereka siap dengan perencanaan yang telah dibuat. Demikian rencana pengumpulan data yang penulis susun. Adapun data hasil penelitian ini yang dipergunakan dalam menganalisis adalah analisis deskriptif. Untuk menganalisis data hasil penelitian ini digunakan model analisis kuantitatif. Ini dilakukan karena data yang diperoleh berupa angka. Cara analisis yang direncanakan adalah mencari mean, median, modus, , interval kelas, penyajian dalam bentuk tabel dan grafik. Yang penulis rencanakan ini hanya sebatas perhitungan yang gampang pada tingkat statistika dasar.

Instrumen dari penelitian ini adalah lembar observasi yang ada di masing-masing RPP. Indikator keberhasilan dari penelitian ini diusulkan pada siklus I dan siklus II mencapai nilai ratarata 86 dengan kualifikasi A (Amat baik) yaitu antara 86-100. Dan ketuntasan pembelajaran yang diharapkan mencapai $80 \%$.

\section{Hasil dan Pembahasan}

Dari Hasil Penelitian Pada bagian ini pemaparan data nyang diperoleh di lapangan disampaikan secara rinci. Untuk dapatnya menyampaikan sesuatu dengan baik, perlu terlebih dahulu menyimak pendapat para ahli.

Dalam menyampaikan hasil penelitian dan pembahasan, perlu menyajikan uraian masing-masing siklus dengan data lengkap mulai dari perencanaan, pelaksanaan, pengamatan/observasi dan repleksi yang berisi penjelasan tentang aspek keberhasilan dan kelemahan yang terjadi. Perlu ditambahkan hal yang mendasar, yaitu hasil perencanaan (kemajuan) pada diri siswa, lingkungan, guru, motivasi dan aktivitas belajar. Kemukakan grafik dan tabelhasil analisis data yang menunjukkan perubahanyang terjadi disertai pembahasan secara sistimatis danjelads (Suhasimi Arikunto, Suhardjono, Supardi, 2006:83).

Sesuai pendapat para ahli di atas, maka dalam pemaparan hasil penelitian ini dimulai dengan hasil perencanaan, hasil pelaksanaan, hasil observasi dan hasil refleksi baik yang diperoleh dari kegiatan siklus I maupun kegiatan di siklus II yang didahului dengan deskripsi awal.

1. Deskripsi Awal

Deskripsi yang dapat disampaikan nuntuk perolehan data awal sebagai indikator yang dituntut yaitu minimal guru mampu mencapai ketuntasan belajar dengan nilai sama atau melebihi ketuntasan belum tercapai. Data yang diperoleh hanya 4 guru yang tuntas atau hanya $19,04 \%$ yang tuntas dari 21 guru di SD Negeri 2 Gianyar pada semester II tahun pelajaran 2017/2018 dengan rata-rata 72,76. Data tersebut menunjukkan rendahnya kemampuan guru di SD Negeri 2 Gianyar dalam melaksanakan proses pembelajaran yang efektif. Kekurangan yang ada adalah akibat proses pembelajaran yang dilakukan oleh guru masih bersifat konvensional. Kelebihannya adalah peneliti sebagai pengawas telah giat melakukan supervisi secara maksimal.

2. Deskripsi Siklus I

Pada siklus I sudah diupayakan untuk perbaikan pembelajaran untuk meningkatkan prestasi dalam melaksanakan proses pembelajaran melalui pelaksanaan supervisi klinis dengan mengikuti alur pembelajaran inquiri selama proses pembelajaran. Peneliti telah giat melakukan kegiatan yang susuai dengan kebenaran teori yang ada sehingga peneliti memperoleh hasil yang lebih baik dari proses awal pembelajaran, yaitu dengan rata-rata nilai 78,38 dari jumlah nilai secara klasikal 1646 dari seluruh guru di SD Negeri 2 Gianyar, dengan prosentase ketuntasan belajarnya adalah $33,33 \%$. Kualifikasi nilai yang diperoleh adalah B (baik) yang ada pada rentang 76-85. Hasil ini belum maksimal, karena belum mecapai indikator keberhasilan penelitian yang mencanangkan dengan minimal prosentase ketuntasan belajar $80 \%$.

3. Deskripsi Siklus II

Dengan tindakan yang sangat maksimal melalui pelaksanaan supervisi klinis dengan mengikuti alur pembelajaran inquiri dalam melaksanakan proses pembelajaran yang efektif di SD Negeri 2 Gianyar, dimana hasil yang diperoleh pada siklus II ini ternyata meningkat secara signifikan dengan nilai rata-rata 89,04 dan ketuntasan belajarnya adalah $100 \%$ dengan kualifikasi nilai yang diperoleh adalah A (amat baik) yang ada pada rentang 86-100.

Pelaksanaan supervisi klinis dengan mengikuti alur pembelajaran inquiri telah diupayakan maksimal. Kendala yang ada adalah pada diri guru yang berlum terbiasa untuk melaksanakan pembelajaran. Mereka masih berpikir bahwa tugas mereka adalah mengajar dan 
belum betul-betul dimengerti. Kebiasaan ini masih muncul dan mendominasi pembelajaran pada siklus I. Guru pada siklus I ini masih tetap berdiri di depan kelas memperlihatkan diri pada pengawas bahwa mereka adalah mengajar. Hal ini akhirnya dipecahkan dengan kembali berdiskusi dengan guru-guru, bertanya jawab baik pada saat pertemuan awal maupun pada saat dilakukan pertemuan balikan. Peneliti giat melakukan diskusi, memberi pengertianpengertian pada mereka dalam upaya menstimulir kegiatan yang dilakukan guru demi adanya perbaikan sesuai arti supervisi. Setelah giat dilakukan upaya untuk perbaikan akhirnya pada siklus I ini nilai guru dapat meningkat walaupun belum sesuai harapan dari usulan keberhasilan penelitian. Dari kemampuan guru awal dengan nilai rata-rata 72,76 dengan ketuntasan hanya mencapai 19,04\%, akhirnya pada siklus I ini dapat ditingkatkan menjadi rata-rata 78,,38 dengan ketuntasan mencapai $33,33 \%$.

Upaya yang lebih giat yang bisa peneliti laksanakan pada siklus yang kedua ini berpenekanan pada perbaikan-perbaikan dari kekurangan-kekurangan yang ada pada diri guru. Semua kekurangan pada siklus I yang sudah disampaikan pada refleksi siklus I di depan menjadi acuan bagi peneliti untuk melakukan perbaikan. Perbaikan ini banyak dilakukan pada pertemuan awal sebelum mereka masuk kelas. Pada saat bimbingan tersebut diberi penekanan agar mereka merubah cara yang mereka lakukan selama ini yaitu mengajar dirubah dengan membelajarkan. Jadi guru tidak diharapkan untuk menceramahkan materi, guru tidak diharapkan menghabiskan waktunya untuk berdiri di depan kelas dan berceramah terus menerus mendominasi kelas. Yang dituntut adalah lebih $60 \%$ waktu digunakan oleh siswa untuk memperoleh pengalaman belajar, jadi guru boleh duduk di bangku guru dan tidak harus terus menerus berdiri ngomong ini, ngomong itu sampai habis waktu pembelajaran tetap juga berdiri. Pada pertemuan awal diberikan bimbingan tentang kekurangan-kekurangan yang ada selama siklus I untuk diperbaiki dan diminta agar guru-guru melihat apa yang mereka tulis di RPP dan melaksanakan sesuai apa yang mereka tulis. Disamping itu guru-guru juga diminta untuk memperhatikan waktu sesuai dengan apa yang mereka telah tulis di RPP. Diskusi yang matang yang dilakukan pada pertemuan awal ternyata mampu menghasilkan peningkatan yang cukup signifikan. Dari rata-rata siklus I adalah 78,38 dengan ketuntasan mencapai $33,33 \%$ pada siklus yang ke II naik menjadi 89,04 dengan ketuntasan mencapai $100 \%$. Keberhasilan ini tidak terlepas dari upaya yang sungguh-sungguh, upaya yang maksimal yang dapat ditujukan untuk peningkatan mutu pendidikan. Rekapitulasi hasil yang dapat disampaikan adalah:

Tabel 1. Rekapitulasi Hasil Penelitian

\begin{tabular}{cccccccccc}
\hline $\begin{array}{c}\text { No Subyek } \\
\text { Penelitian }\end{array}$ & $\begin{array}{c}\text { Perol } \\
\text { ehan }\end{array}$ & $\begin{array}{c}\text { Awal } \\
\text { Rkata- }\end{array}$ & $\begin{array}{c}\text { Rata } \\
\text { Skor }\end{array}$ & $\begin{array}{c}\text { Perole } \\
\text {-han } \\
\text { Skor }\end{array}$ & $\begin{array}{c}\text { Siklus I } \\
\text { Rata- } \\
\text { Rata }\end{array}$ & $\begin{array}{c}\text { \% } \\
\text { Rerol } \\
\text { ehan } \\
\text { Skor }\end{array}$ & $\begin{array}{c}\text { Rata- } \\
\text { Rata }\end{array}$ & $\%$ \\
\hline 1 & 37 & 74 & $74 \%$ & 46 & 92 & $92 \%$ & 45 & 90 & $90 \%$ \\
2 & 34 & 68 & $68 \%$ & 40 & 80 & $80 \%$ & 44 & 88 & $88 \%$ \\
3 & 31 & 62 & $62 \%$ & 36 & 72 & $72 \%$ & 45 & 90 & $90 \%$ \\
4 & 35 & 70 & $70 \%$ & 39 & 78 & $78 \%$ & 45 & 90 & $90 \%$ \\
5 & 33 & 66 & $66 \%$ & 38 & 76 & $76 \%$ & 45 & 90 & $90 \%$ \\
6 & 34 & 68 & $68 \%$ & 39 & 78 & $78 \%$ & 43 & 86 & $86 \%$ \\
7 & 46 & 92 & $92 \%$ & 46 & 92 & $92 \%$ & 47 & 94 & $94 \%$ \\
8 & 40 & 80 & $80 \%$ & 41 & 82 & $82 \%$ & 43 & 86 & $86 \%$ \\
9 & 46 & 92 & $92 \%$ & 46 & 92 & $92 \%$ & 47 & 94 & $94 \%$ \\
10 & 38 & 76 & $76 \%$ & 40 & 80 & $80 \%$ & 44 & 88 & $88 \%$ \\
11 & 34 & 68 & $68 \%$ & 36 & 72 & $72 \%$ & 43 & 86 & $86 \%$ \\
12 & 38 & 76 & $76 \%$ & 39 & 78 & $78 \%$ & 45 & 90 & $90 \%$ \\
13 & 37 & 74 & $74 \%$ & 40 & 80 & $80 \%$ & 44 & 88 & $88 \%$ \\
14 & 33 & 66 & $66 \%$ & 35 & 70 & $70 \%$ & 43 & 86 & $86 \%$ \\
15 & 40 & 80 & $80 \%$ & 40 & 80 & $80 \%$ & 44 & 88 & $88 \%$ \\
16 & 34 & 68 & $68 \%$ & 38 & 76 & $76 \%$ & 46 & 92 & $92 \%$ \\
17 & 37 & 74 & $74 \%$ & 38 & 76 & $76 \%$ & 43 & 86 & $86 \%$ \\
18 & 37 & 74 & $74 \%$ & 37 & 74 & $74 \%$ & 45 & 90 & $90 \%$ \\
19 & 34 & 68 & $68 \%$ & 35 & 70 & $70 \%$ & 44 & 88 & $88 \%$ \\
20 & 31 & 62 & $62 \%$ & 35 & 70 & $70 \%$ & 45 & 90 & $90 \%$ \\
21 & 35 & 70 & $70 \%$ & 39 & 78 & $78 \%$ & 45 & 90 & $90 \%$ \\
Jumlah & & 1528 & & & 1646 & & & 1870 & \\
\hline
\end{tabular}




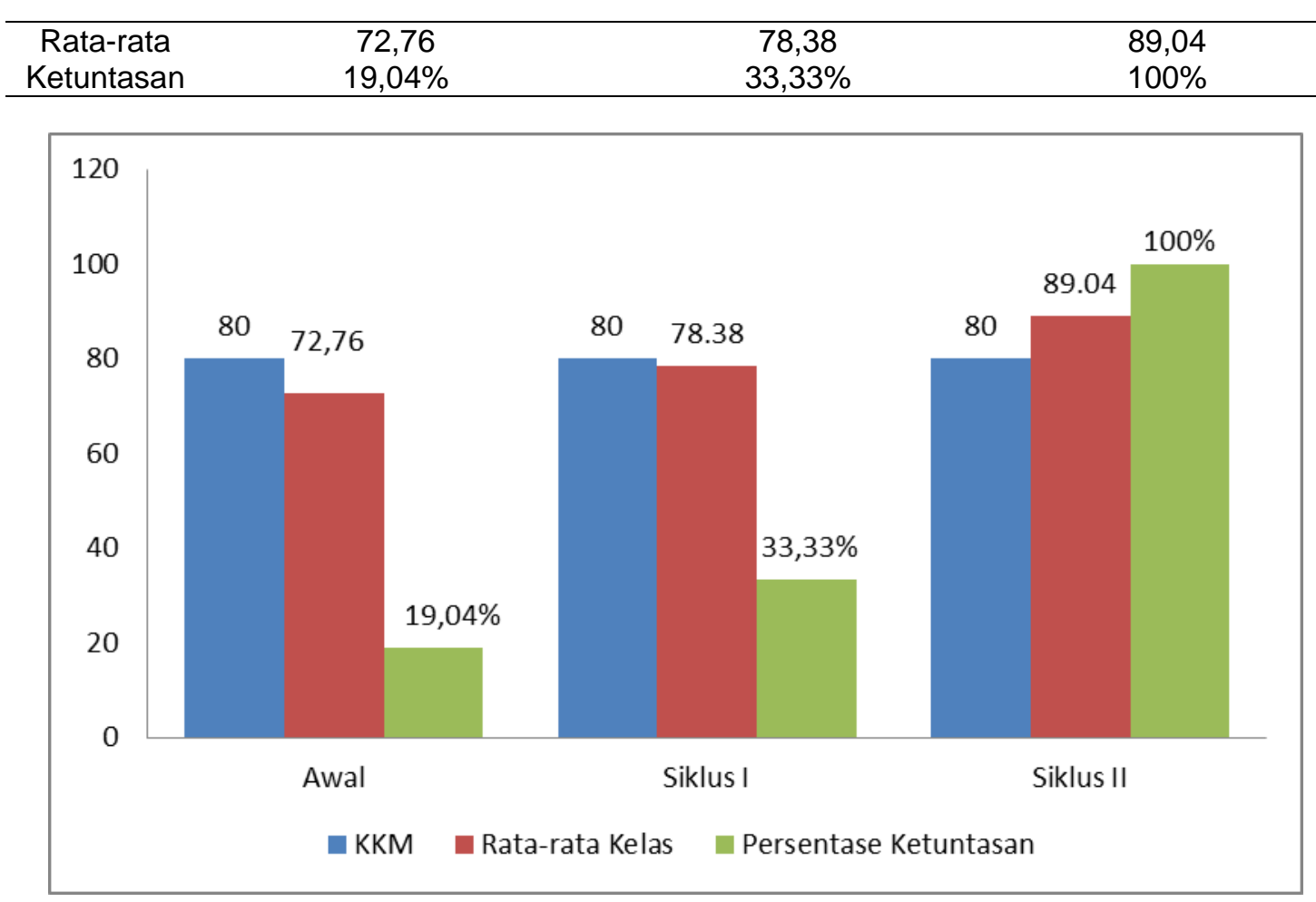

Gambar 2. Penyajian dalam bentuk grafik

Hasil penelitian ini sesuai dengan hasil penelitian yang telah dilakukan oleh Tanama, dkk pada tahun 2016 yang berjudul Implementasi Supervisi Klinis Dalam Meningkatkan Profesionalisme Guru. Hasil penelitian menunjukkan implementasi supervisi klinis yang dilaksanakan dalam tiga tahap yaitu tahap perencanaan, tahap pelaksanaan, dan tahap umpan balik telah berjalan dengan baik dan dapat meningkatkan profesionalisme guru. Berbagai upaya peningkatan dan pengembangan profesional guru telah diusahakan, seperti penguasaan materi, pemilihan metode pembelajaran, dan media yang digunakan.

\section{Simpulan dan Saran}

Melalui supervisi klinis dengan mengikuti alur pembelajaran inquiri dapat meningkatkan kemampuan guru di SD Negeri 2 Gianyar dalam melaksanakan proses pembelajaran yang efektif pada semester II tahun pelajaran 2017/2018. Ini didukung dengan bukti-bukti dari hasil analisis data kemampuan awal guru masih cukup rendah, bahnyak hal belum mampu dilaksanakan sudah dibenahi. Pada siklus I sudah terjadi peningkatan yang lebih baik dimana banyak unsur yang mesti dilakukan dalam proses pembelajaran sudah dilakukan. Pada akhir siklus II bahkan kemampuan guru-guru sudah cukup baik. Hal-hal yang belum dilakukan dalam pelaksanaan proses pembelajaran sebelumnya sudah dilakukan dan terjadi kenaikan nilai yang diharapkan.

Analisis secara kuantitatif sudah membuktikan bahwa melalui supervisi klinis dengan mengikuti alur pembelajaran inquiri dapat meningkatkan kemampuan guru di SD Negeri 2 Gianyar dalam melaksanakan proses pembelajaran yang efektif pada semester II tahun pelajaran 2017/2018. Perolehan skor awal baru mencapai rata-rata 72,76 dengan ketuntasan hanya mencapai $19,04 \%$, membuktikan bahwa kemampuan guru-guru dalam melakukan proses pembelajaran masih rendah namun pada akhir siklus I setelah pelaksanaan supervisi klinis dengan mengikuti alur pembelajaran inquiri mulai dilaksanakan, sudah terjadi peningkatan perolehan skor menjadi 78,38 , bahkan pada akhir siklus II peningkatannya sudah sangat baik dengan perolehan skor 89,04 . Bila dilihat persentase keberhasilannya, pada awalnya baru memperoleh $19,04 \%$, setelah siklus I mencapai $33,33 \%$ dan pada akhir siklus II telah memperoleh peningkatan yang tajam dengan perolehan yang menggembirakan yaitu $100 \%$ dengan kriteria "Amat Baik". 


\section{Daftar Pustaka}

Arikunto Suharsimi, Suhardjono, Supardi. 2006. Penelitian Tindakan. Kelas. Jakarta : Bumi Aksara.

Departemen Pendidikan Nasional. 2006. Manajemen Berbasis Sekolah. Jakarta:

Departemen Pendidikan Nasional. 2009. Kompetensi Supervisi klinis. Jakarta: Dirjen Peningkatan Mutu Pendidik dan Tenaga Kependidikan.

Depdiknas. Departemen Pendidikan Nasional. 2008. Laporan Penelitian Tindakan Sekolah. Jakarta: Depdinas.

Kesuma, Dwi. 2017. Pengembangan profesi guru dalam meningkatkan kinerja guru . Jurnal Pendidikan Manajemen Perkantoran Vol. 2 No. 2, Juli 2017, Hal. 93-101

Kirom, Askhabul. 2017. Peran Guru Dan Peserta Didik Dalam Proses Pembelajaran Berbasis Multikultural . Jurnal Pendidikan Agama Islam Volume 3, Nomor 1, Desember 2017

Lalu Muhammad. 1996. Supervisi Klinis. Surabaya: Penerbit Usaha Nasional.

Megawati, Priarti . 2012. Meretas Permasalahan Pendidikan Di Indonesia . Jurnal Formatif 2(3): 227-234 ISSN: 2088-351X

Munirah. 2015. Sistem Pendidikan Di Indonesia: Antara Keinginan Dan Realita. Jurnal Auladuna, Vol. 2 No. 2 Desember 2015: 233-245

Shabir, M. 2015. Kedudukan Guru Sebagai Pendidik .Jurnal Auladuna, Vol. 2 No. 2 Desember 2015: 221-232

Sukmadinata, Nana Syaodih. 2007. Metode Penelitian Pendidikan. Bandung: Rosdakarya.

Tanama, Yulia Jayanti, dkk. 2016. Implementasi Supervisi Klinis Dalam Meningkatkan Profesionalisme Guru. Jurnal Pendidikan: Teori Penelitian dan Pengembangan Volume 1 Nomor 1 November 2016, Halaman 2231-2235.

Warsono . 2017. Guru: Antara Pendidik, Profesi, Dan Aktor Sosial . Journal of Society \& Media 2017, Vol. 1(1) 1-10 